\title{
Hyperinsulinemia Is Associated with Altered Insulin Receptor mRNA Splicing in Muscle of the Spontaneously Obese Diabetic Rhesus Monkey
}

\author{
Ze Huang, Noni L. Bodkin, ${ }^{*}$ Heidi K. Ortmeyer, ${ }^{*}$ Barbara C. Hansen, ${ }^{*}$ and Alan R. Shuldiner \\ Department of Medicine, Johns Hopkins University School of Medicine, and *Department of Physiology, University of Maryland School \\ of Medicine, Baltimore, Maryland 21224
}

\begin{abstract}
The human insulin receptor has two isoforms derived from alternative splicing of exon 11 of the insulin receptor gene. The type B (containing exon 11, or exon 11+) isoform binds insulin with twofold lower affinity than the type $A$ (lacking exon 11, or exon 11-) isoform. In efforts to resolve the controversy over whether altered splicing is involved in the development of insulin resistance and non-insulin-dependent diabetes mellitus (NIDDM), the spontaneously obese diabetic rhesus monkey, a unique model that is extraordinarily similar to human NIDDM, was used. Cross-sectional studies of insulin receptor mRNA splicing variants in vastus lateralis muscle were performed on 19 rhesus monkeys. When monkeys were divided into four groups based upon the known stages of progression to NIDDM: normal (normoglycemic/normoinsulinemic), prediabetic (normoglycemic/hyperinsulinemic), early NIDDM (hyperglycemic/hyperinsulinemic), and late NIDDM (hyperglycemic/ hypoinsulinemic), both hyperinsulinemic groups had significantly higher percentages of the exon 11- mRNA splicing variant compared to the normal $(74.8 \pm 1.7$ vs 59.0 $\pm 2.3 \%$; $P<0.005)$ and late NIDDM groups $(74.8 \pm 1.7$ vs $64.2 \pm 3.9 \% ; P<0.05)$. Our findings provide the first direct evidence linking hyperinsulinemia to alterations in insulin receptor mRNA splicing, and suggest that alterations of insulin receptor mRNA splicing in muscle is an early molecular marker that may play an important role in NIDDM. (J. Clin. Invest. 1994. 94:1289-1296.) Key words: insulin receptor isoforms - mRNA splicing - insulin resistance • non-insulin-dependent diabetes mellitus • obesity
\end{abstract}

\section{Introduction}

Non-insulin-dependent diabetes mellitus (NIDDM) ${ }^{1}$ is one of the most common human diseases, and is characterized by insulin resistance in all major target tissues, especially skeletal mus-

Address correspondence to Alan R. Shuldiner, M.D., Johns Hopkins University School of Medicine, Hopkins Bayview Research Campus, JHAAC, 5501 Bayview Circle, Room 5A-42, Baltimore, MD 21224.

Received for publication 17 March 1994 and in revised form 10 May 1994.

1. Abbreviations used in this paper: NIDDM, non-insulin-dependent diabetes mellitus; RS-PCR, RNA template-specific polymerase chain reaction; RT-PCR, reverse transcription-polymerase chain reaction.

J. Clin. Invest.

(c) The American Society for Clinical Investigation, Inc.

0021-9738/94/09/1289/08 $\$ 2.00$

Volume 94, September 1994, 1289-1296 cle, as well as $\beta$-cell dysfunction $(1,2)$. A number of candidate genes and their protein products that are involved in the pathways leading to insulin action have been implicated as potential molecular defects leading to NIDDM (1-6). However, the molecular basis of insulin resistance associated with typical NIDDM remains unknown.

The human insulin receptor gene is a single-copy gene located on the short arm of chromosome 19, consisting of 22 exons spanning more than $120 \mathrm{~kb}$. It encodes a transmembrane protein consisting of two extracellular $\alpha$-subunits and two transmembrane $\beta$-subunits $\left(\alpha_{2} \beta_{2}\right)$. Insulin binds extracellularly, leading to autophosphorylation and activation of the receptor's tyrosine kinase. Subsequent phosphorylation of endogenous substrates leads to some or all of the actions of insulin (5-9).

Mutations in the insulin receptor gene have been identified in patients with rare genetic syndromes of extreme insulin resistance (10). However, these mutations are very rare among patients with the mild to moderate insulin resistance commonly observed in typical NIDDM (11). Since some studies have shown qualitative or quantitative differences in insulin binding, phosphorylation, or signal transduction in NIDDM, other potential molecular defects in the insulin receptor may be present ( 1 , $2,4,5)$.

The human insulin receptor has two isoforms which are derived from alternative mRNA splicing of the short (36 bp) exon 11. The type B (containing exon 11 , or exon $11+$ ) isoform has 12 additional amino acids at the carboxy terminus of the $\alpha$-subunit, while the type A (lacking exon 11, or exon 11-) isoform does not contain these amino acids $(12,13)$. The exon $11+$ isoform binds insulin with twofold lower affinity (1416). However, the relative ability of each receptor isoform to transduce downstream events leading to insulin action is less certain (17-21). It is appealing to speculate that alterations in mRNA splicing may be responsible, at least in part, for insulin resistance and NIDDM. In fact, others have shown both at the mRNA and protein levels that the exon $11+$ receptor isoform is markedly increased in the muscles of subjects with NIDDM, compared with nondiabetic controls (22-26). These findings could not be substantiated by other groups $(27,28)$. The reason for the discrepancies between studies is unclear, but it may be due to differences in patient and tissue selection, control groups, experimental methods, or other confounding variables. Obvious limitations in all of these studies include difficulty in obtaining samples from multiple tissues in humans and the lack of good longitudinal data.

The spontaneously obese diabetic rhesus monkey is extraordinarily similar to human NIDDM with respect to its clinical presentation and underlying pathophysiology (29-31). When maintained in a protective environment and allowed ad lib. access to food, rhesus monkeys frequently develop obesity and insulin resistance, and many of the obese go on to develop diabetes. Longitudinal studies indicate that in monkeys, as in 
Table I. Characteristics of Rhesus Monkeys Used to Study Exon 11 Alternative mRNA Splicing

\begin{tabular}{|c|c|c|c|c|c|c|c|c|}
\hline Group* & $\begin{array}{c}\text { Monkey } \\
\text { No. }\end{array}$ & $\mathrm{Age}^{\ddagger}$ & Weight & $\begin{array}{l}\text { Fasting } \\
\text { glucose }\end{array}$ & $\begin{array}{l}\text { Fasting } \\
\text { insulin }\end{array}$ & $\begin{array}{l}\text { Body } \\
\text { fat }\end{array}$ & $K_{\text {glucose }}$ & Exon 11- \\
\hline & & $y r$ & $k g$ & $m g / d l$ & $\mu U / m l$ & $\%$ & & $\%$ \\
\hline \multirow[t]{6}{*}{ Normal (normoglycemic/normoinsulinemic) } & M1 & 13.5 & 14.3 & 59 & 63 & 35.3 & 3.27 & 66.6 \\
\hline & M2 & 13.7 & 11.8 & 65 & 60 & 30.8 & 3.03 & 50.1 \\
\hline & M3 & 13.2 & 10.6 & 67 & 37 & 24.3 & 4.31 & 60.0 \\
\hline & M4 & 28.6 & 9.2 & 70 & 76 & 39.8 & 0.86 & 62.9 \\
\hline & M5 & 13.6 & 12.8 & 65 & 44 & 19.1 & 2.86 & 59.1 \\
\hline & M6 & 10.4 & 11.1 & 77 & 52 & - & 2.51 & 55.3 \\
\hline \multirow[t]{6}{*}{ Prediabetic (normoglycemic/hyperinsulinemic) } & M7 & 26.4 & 12.8 & 69 & 98 & 31.6 & 3.36 & 74.8 \\
\hline & M8 & 16.8 & 14.9 & 76 & 198 & 32.1 & 2.49 & 81.8 \\
\hline & M9 & 11.8 & 14.9 & 61 & 92 & 24.7 & 2.32 & 76.4 \\
\hline & M10 & 20.3 & 12.0 & 79 & 163 & 25.3 & 2.76 & 67.7 \\
\hline & M11 & 22.8 & 16.9 & 74 & 174 & 41.7 & 2.06 & 71.3 \\
\hline & M12 & 24.8 & 23.0 & 75 & 119 & 34.7 & 1.43 & 81.2 \\
\hline \multirow[t]{2}{*}{ Early NIDDM (hyperglycemic/hyperinsulinemic) } & M13 & 10.4 & 13.0 & 157 & 1637 & 33.0 & 1.82 & 72.2 \\
\hline & M14 & 16.4 & 17.9 & 164 & 402 & 30.1 & 1.08 & 72.7 \\
\hline \multirow[t]{5}{*}{ Late NIDDM (hyperglycemic/hypoinsulinemic) } & M15 & 25.7 & 11.5 & 162 & 7 & 46.5 & 1.15 & 56.2 \\
\hline & M16 & 24.2 & 10.6 & 211 & 19 & 39.7 & 1.22 & 62.5 \\
\hline & M17 & 18.8 & 9.2 & 220 & 28 & 18.3 & 1.24 & 72.9 \\
\hline & M18 & 31.8 & 6.6 & 372 & 17 & 12.1 & 1.31 & 56.0 \\
\hline & M19 & 25.9 & 13.4 & 268 & 19 & 21.0 & 0.56 & 74.5 \\
\hline
\end{tabular}

* Monkeys were characterized periodically, and the set of values closest to the time that the muscle sample was obtained is shown. Normoglycemic, fasting glucose $<140 \mathrm{mg} / \mathrm{dl}$; hyperglycemic, fasting glucose $>140 \mathrm{mg} / \mathrm{dl}$; hyperinsulinemic, fasting insulin $>80 \mu \mathrm{U} / \mathrm{ml}$; hypoinsulinemic, fasting insulin $<30 \mu \mathrm{U} / \mathrm{ml}$. ${ }^{\ddagger}$ One monkey year equals approximately 3 human years.

humans, early markers of impending diabetes include insulin resistance (particularly in muscle) and hyperinsulinemia. Later in the course of the disease, there is declining $\beta$-cell function and increased hepatic glucose output, and hyperglycemia and NIDDM ensue.

To explore further whether altered splicing of exon 11 of the insulin receptor gene is involved in the development of insulin resistance and NIDDM, we now report the cloning of cDNAs corresponding to exons 9 through 12 of the rhesus insulin receptor gene, and measurement of the relative amounts of the two mRNA splicing variants in normal, prediabetic, and diabetic monkeys.

\section{Methods}

Animals. Adult rhesus monkeys (Macaca mulatta) under longitudinal study in the Obesity and Diabetes Research Center at the University of Maryland School of Medicine were used in this study (Table I). Animals were individually housed in stainless steel primate cages and maintained under constant conditions according to the National Institutes of Health Guide for the Care and Use of Laboratory Animals. Either standard monkey chow (Ralston Purina Co., St. Louis, MO) or a complete liquid diet of Ensure ${ }^{\mathrm{TM}}$ (Ross Laboratories Div., Columbus, $\mathrm{OH}$ ) were provided ad lib. Fresh water was also provided ad lib.

Monkeys were characterized according to intravenous glucose tolerance tests, body fat determinations, and euglycemic hyperinsulinemic clamps. Plasma glucose was measured using the glucose oxidase method on a Glucose Autoanalyzer II (Beckman Instruments Inc., Fullerton, CA). Plasma insulin was measured by the double-antibody radioimmunoassay.
Tissue was obtained from monkeys either under ketamine hydrochloride anesthesia (10-15 mg/kg body wt) or immediately following killing by intravenous injection of sodium pentobarbital. Tissue was frozen immediately in liquid nitrogen, and stored at $-165^{\circ} \mathrm{C}$. Some samples were lyophilized before long-term storage.

RNA isolation. Total RNA was extracted from monkey tissues (10$1,000 \mathrm{mg}$ ) using the RNAzol method (Cinna/Biotecx Laboratories, Friendswood, TX) according to the manufacturer's instructions. RNA was quantitated spectrophotometrically. The integrity of the RNA was determined by gel electrophoresis, ethidium bromide staining, and ultraviolet transillumination.

Oligonucleotide synthesis. Oligonucleotides were synthesized on an automated DNA synthesizer (Applied Biosystems Inc., Foster City, CA), cleaved from the resin with concentrated ammonium hydroxide at room temperature, and deprotected by heating to $55^{\circ} \mathrm{C}$ overnight. Oligonucleotides were desalted through a G-25 spin column (Boehringer Mannheim Corp., Indianapolis, IN) and used without further purification.

Cloning of exons 9 through 12 of the rhesus insulin receptor gene. Reverse transcription-polymerase chain reaction (RT-PCR), was used to obtain the nucleotide sequence of the rhesus insulin receptor gene in the region of interest. Briefly, $5 \mu \mathrm{g}$ of total RNA from the liver of a nondiabetic monkey was reverse transcribed at $37^{\circ} \mathrm{C}$ for $1 \mathrm{~h}$ in a final volume of $20 \mu \mathrm{l}$, containing $1 \times$ PCR buffer ( $50 \mathrm{mM} \mathrm{KCl}, 10 \mathrm{mM}$ Tris, $\mathrm{pH} 8.3$ at $25^{\circ} \mathrm{C}, 1.5 \mathrm{mM} \mathrm{MgCl}, 0.01 \mathrm{mg} / \mathrm{ml}$ gelatin ), $200 \mu \mathrm{M}$ of each dnucleoside triphosphate (dNTP) (Perkin-Elmer Cetus Instr., Emeryville, CA), $2 \mathrm{U} / \mu \mathrm{l}$ RNasin (Promega Corp., Madison, WI), $0.35 \mathrm{U} / \mu \mathrm{l}$ avian myeloblastosis virus (AMV)-reverse transcriptase (Promega Corp.) and $0.5 \mu \mathrm{M}$ downstream (antisense) primer (5'-CTTCAGGCATGGTCCTCGCACT-3') corresponding to a region within exon 12 of the human insulin receptor gene. $5 \mu \mathrm{l}$ of the reverse transcription reaction mixture were amplified by PCR in a final volume of $50 \mu$ l containing 
Figure 1. cDNA sequence of the rhesus monkey insulin receptor (exons 9 through 12) and the predicted amino acid sequence. Nucleotides that differ between rhesus and human are shown in bold and are underlined. Nucleotides corresponding to exon 11 are underlined twice. The 753 exon 11 splice junctions were deduced by comparison of rhesus clones with and

773 without exon 11. The asterisk at codon 761 depicts the single predicted amino Val Val Asn Lys Glu Ser Leu Val Ile Ser Gly Leu Arg His Phe Thr Gly Tyr Arg Ile acid difference between human and rhesus sequences $\left(\mathrm{Val}^{\mathrm{GTG}} \rightarrow \mathrm{Thr}^{\mathrm{ACG}}\right)$. These sequence data are available from GenGAG CTG CAG GCT TGC AAC CAM GAC ACC CCT GAG GAA CGG TGC AGT GTG GCA GCC TAC GTC

$1 \times$ PCR buffer, $200 \mu \mathrm{M}$ of each $d \mathrm{NTP}, 1.5 \mathrm{U} /$ tube of Thermus aquaticus (Taq) polymerase (Perkin-Elmer Cetus Instr.), and $0.5 \mu \mathrm{M}$ each of the same downstream primer that was used for reverse transcription and upstream (sense) primer (5'-TCTGTGCCCCTGGATCCAATCTC-3') corresponding to a region within exon 9 of the human insulin receptor gene. 37 cycles of PCR were performed, each cycle consisting of denaturation $\left(1 \mathrm{~min}\right.$ at $\left.94^{\circ} \mathrm{C}\right)$, annealing $\left(1 \mathrm{~min}\right.$ at $\left.65^{\circ} \mathrm{C}\right)$, and extension $\left(1 \mathrm{~min}\right.$ at $\left.72^{\circ} \mathrm{C}\right)$, except that in the first cycle, the denaturation time was increased to $5 \mathrm{~min}$, and in the last cycle the extension time was increased to $10 \mathrm{~min}$.

Cloning and DNA sequence analysis. The expected 640 bp (exon $11-$ ) and 676 bp (exon 11+) PCR products were ligated into pCRII (Invitrogen, San Diego, CA) using established methods. Recombinant plasmids were used to transform competent DH5a Escherichia coli (Bethesda Research Laboratories, Gaithersburg, MD), and transformants were selected on agar plates containing ampicillin and X-gal (5-bromo-4-chloro-3-indolyl- $\beta$-D-galactopyranoside). Plasmid DNA was prepared from colorless colonies (Qiagen, Chatsworth, CA). Dideoxy-sequence analysis was performed using established methods $(\mathrm{K} /$ RT sequencing kit; Promega Corp.). Two independent PCR reactions were performed, and clones from each were sequenced to exclude potential PCR artifacts.

Quantitation of the relative amounts of the two insulin receptor mRNA splicing variants. The relative amounts of mRNA corresponding to the exon $11-$ and exon $11+$ insulin receptor isoforms were determined using RNA template-specific PCR (RS-PCR), ${ }^{1}$ developed in our laboratory. RS-PCR has equal sensitivity to conventional RT-PCR, but dramatically reduces the frequency of false positives (32). Briefly, reverse transcription was performed as described above with primer $\mathrm{d}_{17} \mathrm{t}_{30}$ (5'-CGTATCAGCAGATCCTAGGAATTCTCGGACTTGTTC ACCACCTTCTC-3') which contains 17 bases at its $3^{\prime}$ end (segment

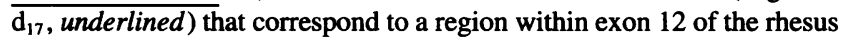
insulin receptor gene, and a unique 30-base tag (segment $t_{30}$ ) at its $5^{\prime}$ end. The resulting cDNA containing the unique 30-base tag at its $5^{\prime}$ end was amplified by PCR with upstream (sense) primer ( 5 '-CACCATTCGAGTCTGAAGATTCTCAGAAGC-3') corresponding to a region within exon 9 of the rhesus insulin receptor gene, and downstream (antisense) primer $t_{30}$ (5'-CGTATCAGCAGATCCTAGGAATTCTCGGAC-3') corresponding to the unique 30-base tag. $0.1 \mu$ l per tube of $\alpha$ - $\left.{ }^{32} \mathrm{P}\right] d$-cytidine 5 '-triphosphate (dCTP) $(3,000 \mathrm{Ci} / \mathrm{mmol}$; Amersham Corp., Arlington Heights, IL) was incorporated directly into the PCR product. PCR reaction concentrations and conditions were essen- tially the same as those described above, except 34 cycles were performed.

The two resulting radiolabeled PCR products differed in size by 36 bp ( 382 bp versus $346 \mathrm{bp}$ ), and were separated on a $6 \%$ denaturing polyacrylamide gel. The gel was dried and autoradiography was performed. The relative amounts of the two mRNA splicing variants were quantitated using a beta scanner (Betagen, Waltham, MA). Data were corrected by subtracting background and adjusting for the additional cytosines in the larger (exon 11+) variant. To confirm that the two mRNA splicing variants were being amplified in an unbiased manner, known ratios of the in vitro synthesized RNA corresponding to the two mRNA splice variants were amplified and quantitated.

Statistical methods. The relative amount of the exon 11- (type A) variant was calculated as a percentage of total (exon 11- plus exon $11+$ ), and expressed as the mean \pm SEM. One-way ANOVA was performed to determine if means were different by groups. Scheffe's $S$ was used to control for multiple comparisons. Differences in regional distribution of the mRNA splicing variants in fat and muscle were determined using a paired $t$ test. Spearman regression was used for correlation analysis. The level of significance accepted was $P \leq 0.05$.

\section{Results}

Characterization of exons 9 through 12 of the rhesus insulin receptor gene. To study insulin receptor mRNA splicing in the spontaneously obese and diabetic rhesus monkey, we first used a PCR-based cloning strategy to obtain a cDNA sequence corresponding to exons 9 through 12 of the rhesus insulin receptor gene. RT-PCR of rhesus liver RNA with primers derived from the human insulin receptor sequence followed by subcloning resulted in two products, 640 and 676 bp in length. Sequence analysis revealed that the longer clone contained exon 11 , while the shorter clone lacked exon 11. These findings confirm that like the human, the rhesus monkey has two insulin receptor mRNA splicing variants. The rhesus insulin receptor gene is very similar to human ( $98.4 \%$ nucleotide identity, $99.5 \%$ amino acid identity) (7-9), rat (90\% amino acid identity) (33), and mouse (89.9\% amino acid identity) (34) in the region studied (Figs. 1 and 2). 


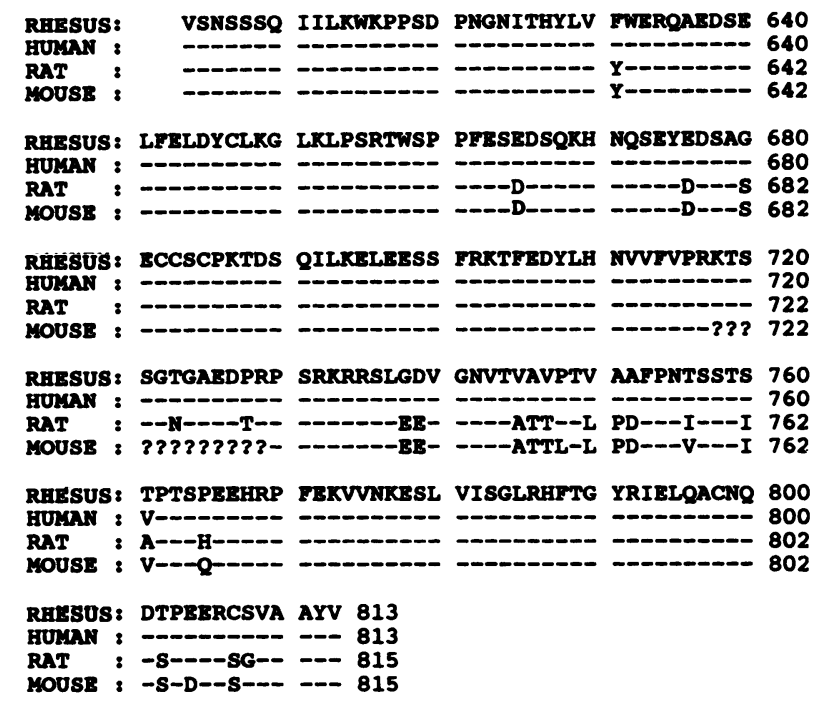

Figure 2. Comparison of the predicted amino acid sequence of the rhesus insulin receptor (exons 9 through 12) with other species. Hyphens indicate amino acid identity with rhesus (human, $99.5 \%$; rat, $90 \%$; mouse, $89.9 \%$ ). The sequence of exon 11 in mouse amino acids $719-731$ is not known.

Quantitation of the relative amounts of the two insulin receptor mRNA splicing variants. For accurate quantitation of the two insulin receptor mRNA splicing variants, we used RS-PCR, a modified reverse transcription-PCR assay (32). Primers were designed that flanked the exon 11 splice junctions (Fig. $3 \mathrm{~A}$ ). To determine if the two mRNA splicing variants were being amplified in an unbiased manner, a validation experiment was performed. In vitro synthesized rhesus insulin receptor RNA containing or lacking exon 11 were mixed in varying ratios, and RS-PCR was performed (Fig. $3 B$ ). The PCR product output ratios were virtually identical to the RNA input ratios ( $r$ $=0.999$ ) confirming that the two mRNA splicing variants were being amplified in an unbiased manner (Fig. $3 C$ ). A cycle titration revealed that 34 cycles was within the logarithmic phase of amplification (data not shown).

Tissue-specific expression of the two insulin receptor $m R N A$ splicing variants in the rhesus monkey. To discern the relative amounts of the two insulin receptor mRNA splicing variants in various tissues, RS-PCR was performed from RNA extracted from rectus abdominis muscle, intraabdominal fat, liver, stomach, heart, kidney, brain, and spleen of monkeys ranging from normal to NIDDM (Fig. 4). The relative amounts of insulin receptor mRNA splicing variants between various tissues were found to vary greatly. For example, the tissue containing the least exon 11- mRNA variant was liver $(36.6 \pm 4.0 \%$ exon 11-), while the tissues containing the most exon 11- mRNA variant were spleen $(94.5 \pm 1.5 \%$ exon $11-)$ and brain $(97.0 \pm 1.0 \%$ exon $11-)$. Tissues with an intermediate relative amount of the exon $11-$ variant included rectus abdominis muscle $(67.0 \pm 3.9 \%)$, heart $(65.7 \pm 6.7 \%)$, stomach $(75.1 \pm 4.5 \%)$, intraabdominal fat $(77.2 \pm 2.8 \%)$, and kidney $(77.1 \pm 3.3 \%)$. The pattern of tissue-specific expression of the two insulin receptor mRNA splicing variants was similar to that found in humans and rats, except that monkeys tended to have more of the exon 11 - variant $(12,13,33)$.

Regional distribution of insulin receptor mRNA splicing

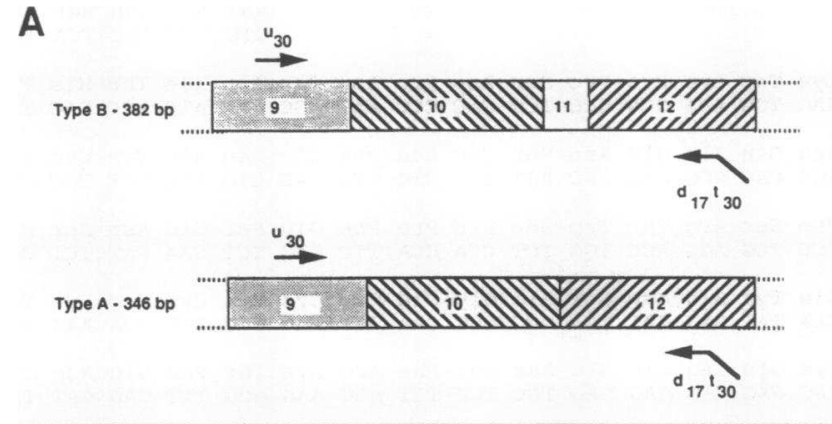

$\mathbf{B}$
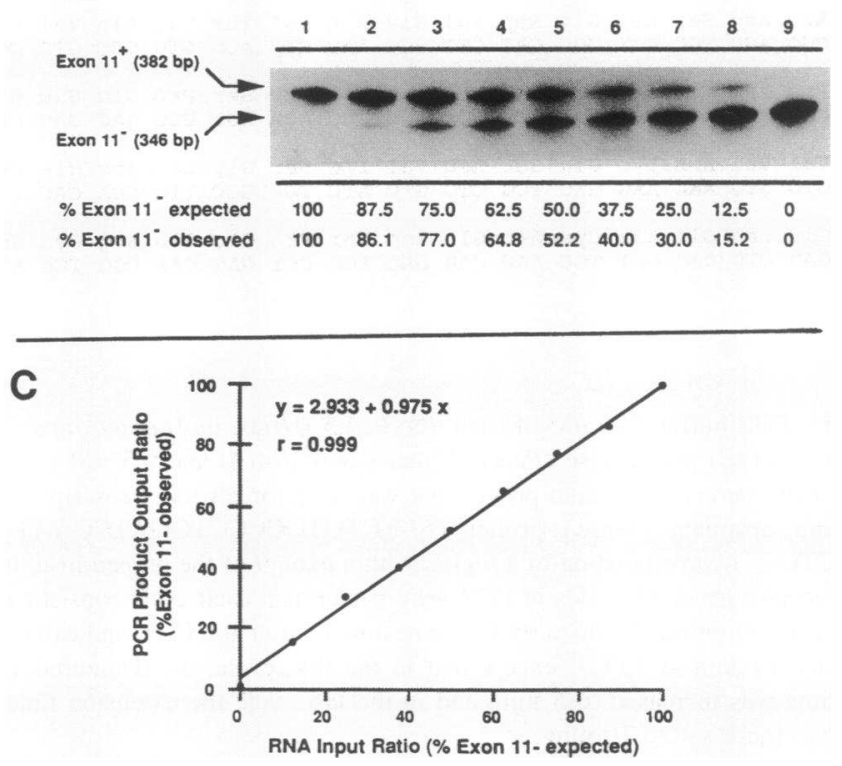

Figure 3. Validation of RNA template-specific PCR (RS-PCR) for measuring the relative amounts of insulin receptor $\mathrm{mRNA}$ splicing variants. $(A)$ Schematic of primer design. Upstream primer $\left(u_{30}\right)$ and downstream primer $\left(d_{17} t_{30}\right)$ flank the exon 11 splice junction. RS-PCR with these primers results in two products with predicted sizes $346 \mathrm{bp}$ (exon $11-)$ and 382 bp (exon 11+). (B) Varying ratios of in vitro synthesized RNA corresponding to exon 11 - and exon $11+$ were mixed (\% exon 11 - expected), and RS-PCR was performed in the presence of [ $\left.{ }^{32} \mathrm{P}\right]$ $d C T P$. After electrophoresis and autoradiography, the amount of radioactivity in each band was quantitated using a beta scanner, and the percent exon 11- mRNA variant was calculated (\% exon $11-$ observed). (See text for details of methods.) (C) Plot of data generated from experiment shown in $B$.

variants in fat and muscle. To determine whether there are regional differences in the relative expression of the two insulin receptor mRNA splicing variants in muscle and in fat, two regions of muscle (vastus lateralis and rectus abdominis) and two regions of fat (subcutaneous abdominal and intraabdominal) were obtained from five monkeys (one normal, three prediabetic, and one late NIDDM). Interestingly, a small but significant difference in regional distribution of the two insulin receptor mRNA splicing variants was found in muscle: vastus lateralis $72.9 \pm 4.1 \%$ versus rectus abdominis $67.0 \pm 3.9 \%(P=$ 0.02 ) (Fig. 5). By contrast, no consistent difference was found between subcutaneous abdominal and intraabdominal fat in these same monkeys $(80.3 \pm 1.7$ vs $77.2 \pm 2.8 \% ; P=\mathrm{NS})$ (Fig. 5). 

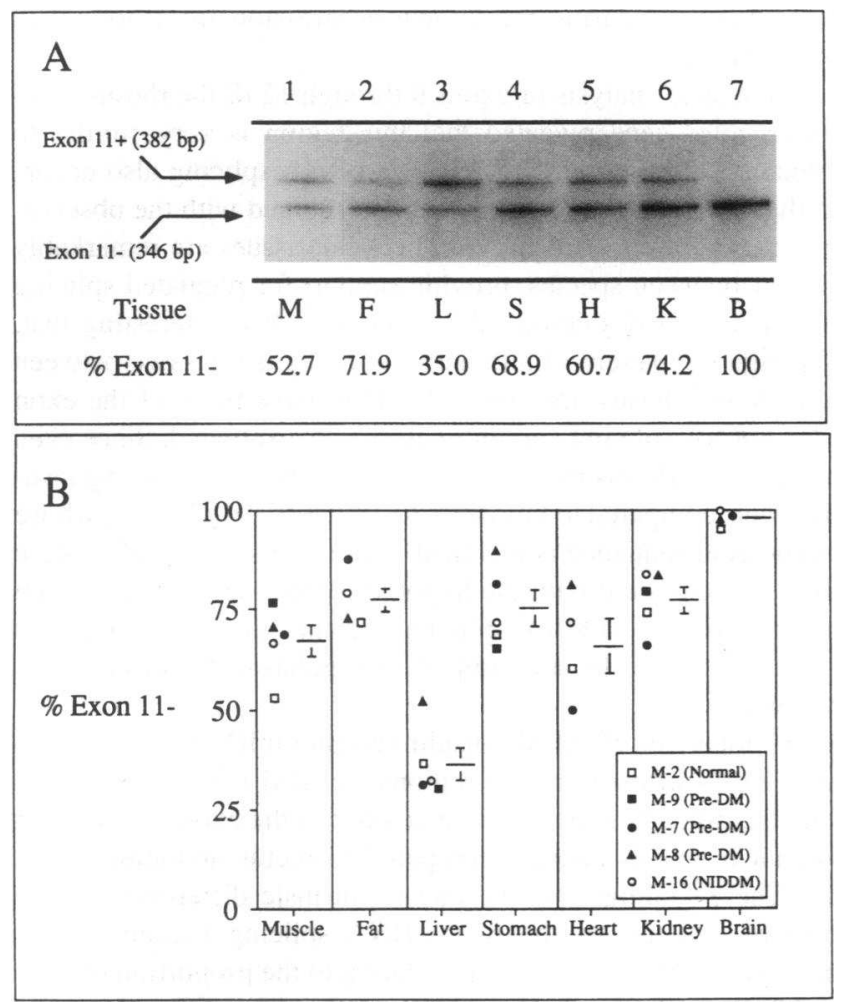

Figure 4. Tissue-specific expression of insulin receptor mRNA splicing variants in rhesus monkeys. $(A)$ Total RNA from rectus abdominis muscle (M), intraabdominal fat (F), liver (L), stomach (S), heart $(H)$, kidney (K), and brain (B) from a normal monkey (M2) were subjected to RS-PCR, and the percent exon 11- mRNA splicing variant was quantitated as described. $(B)$ Data from five monkeys ranging from normal to NIDDM (M2, M7, M8, M9, M16). The pattern of tissuespecific expression of the two insulin receptor mRNA splicing variants was similar to that found in humans and rats except that the monkeys tended to have more of the exon 11- mRNA splicing variant. The experiment was repeated twice with virtually identical results.
Cross-sectional analysis of insulin receptor mRNA splicing variants in muscle of nondiabetic and diabetic rhesus monkeys. To determine whether there are alterations in the relative amounts of the two insulin receptor mRNA splicing variants between nondiabetic and diabetic rhesus monkeys, the relative amounts of the exon $11-$ and exon $11+$ receptor mRNA variants were determined in the skeletal muscle (vastus lateralis) from 19 monkeys which were at different stages ranging from normal to overtly diabetic (Table I). Measurement of the relative amounts of the two insulin receptor mRNA splicing variants revealed that there were no differences between normoglycemic and diabetic monkeys (Fig. 6 A). However, when monkeys were divided into four groups based upon the known natural progression of diabetes in monkeys and humans: normal (normoglycemic/normoinsulinemic), prediabetic (normoglycemic/hyperinsulinemic), early NIDDM (hyperglycemic/hyperinsulinemic), and late NIDDM (hyperglycemic/hypoinsulinemic), the percent exon 11- mRNA variant was significantly higher in hyperinsulinemic monkeys $(74.8 \pm 1.7 \%)$, than in normal $(59.0 \pm 2.3 \% ; P<0.005)$ or late NIDDM (64.2 \pm 3.9 ; $P<0.05$ ) (Fig. 6, $B-D$ ). In addition, fasting plasma insulin was significantly correlated with the percent exon 11- mRNA variant $(r=0.537 ; P<0.02)$. The relative amounts of the exon 11- mRNA splicing variant did not correlate significantly with age, body weight, percent body fat, or $K_{\text {glucose }}$. These data provide the first evidence that insulin receptor mRNA splicing is related to the amount of circulating insulin (and not glucose) in vivo.

\section{Discussion}

The spontaneously obese and diabetic rhesus monkey is a wellcharacterized model with clinical presentation and progressive changes in insulin sensitivity and $\beta$ cell function that are remarkably similar to human NIDDM (29-31). This observation, coupled with the accessibility of multiple tissues from carefully characterized monkeys, has provided the rationale for studying the role of alternate mRNA splicing of exon 11 of the insulin

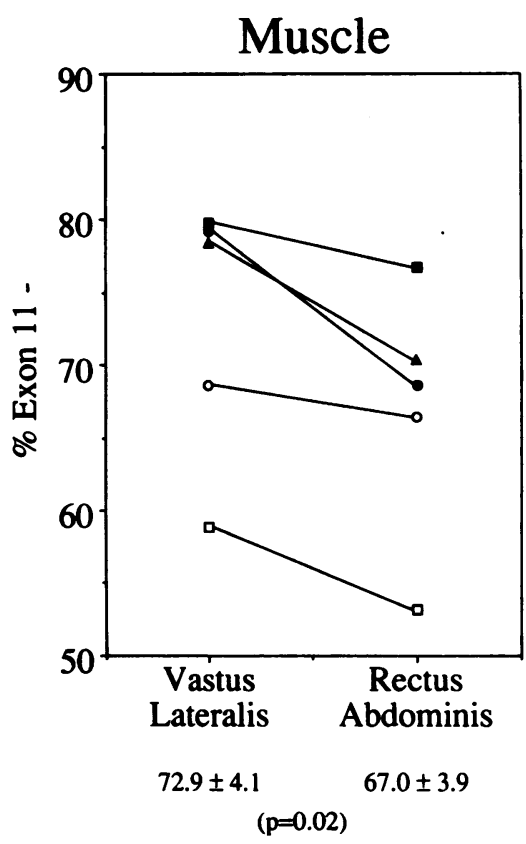

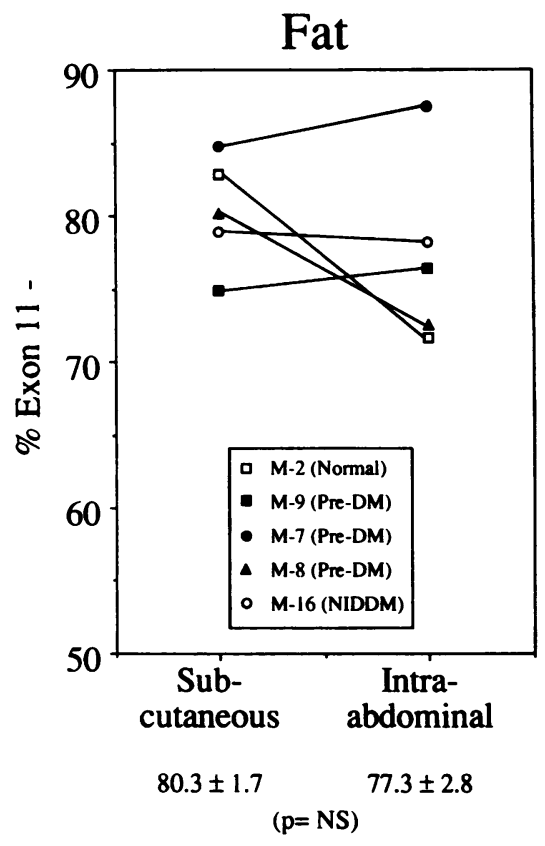

Figure 5. Regional distribution of insulin receptor mRNA splicing variants in fat and muscle. Muscle from two different regions (vastus lateralis and rectus abdominis) and fat from two different regions (subcutaneous abdominal and intraabdominal) were obtained from five monkeys: one normal (M2), three prediabetic (M7, M8, M9), and one late NIDDM (M16) (also see Table I). RS-PCR was performed, and the percent exon 11- was quantitated as described. Muscle from vastus lateralis contained more of the mRNA encoding the exon 11isoform than muscle from rectus abdominis in all monkeys (72.9 \pm 4.1 vs. $67.0 \pm 3.9 \% ; P=0.02$ ). By contrast, no regional difference was found between subcutaneous abdominal and intraabdominal fat. The experiment was repeated twice with virtually identical results. 

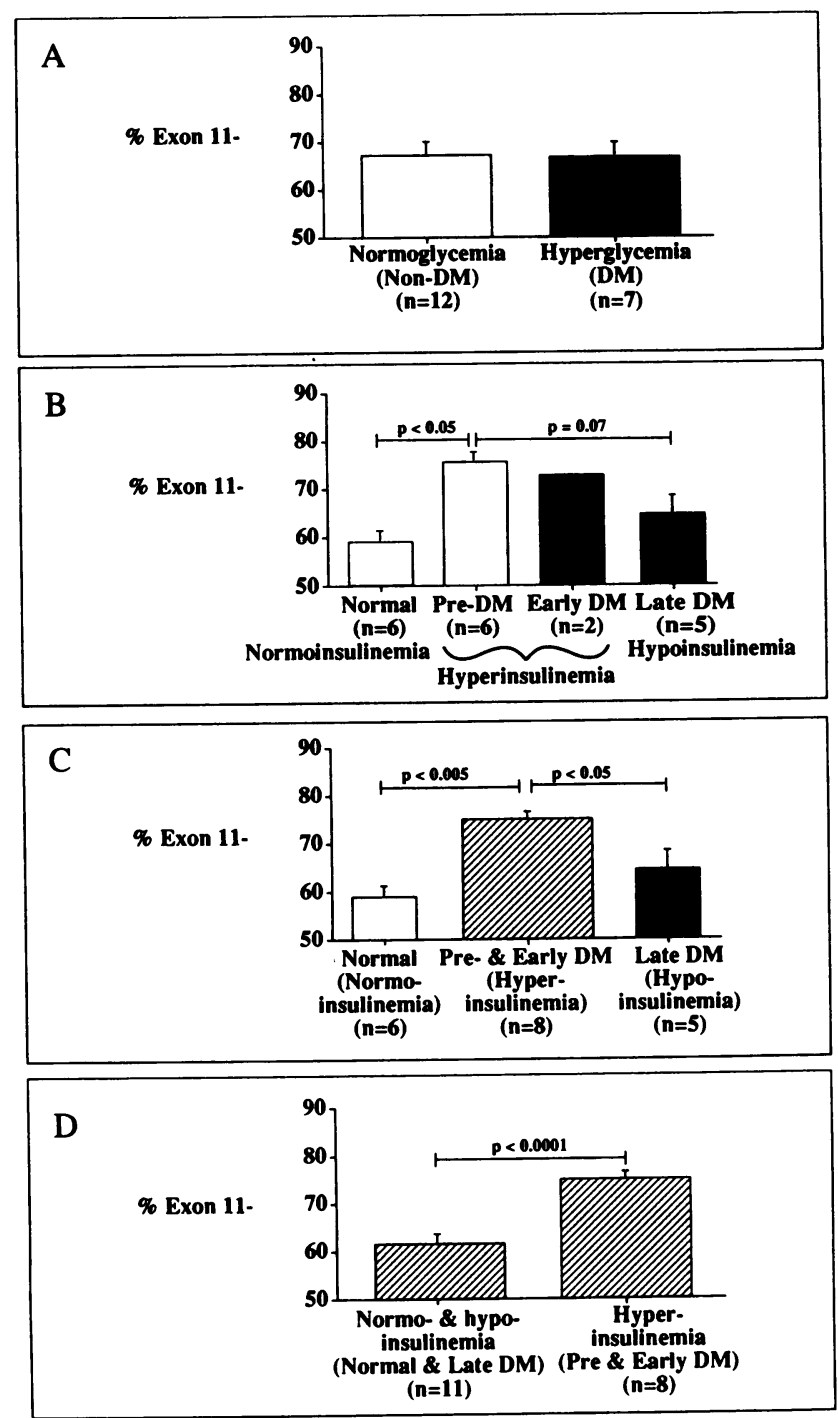

Figure 6. Cross-sectional analysis of insulin receptor mRNA splicing variants. Characteristics of the 19 monkeys are shown in Table I. RNA from muscle was subjected to RS-PCR, and the percent exon 11- was quantitated as described. $(A)$ Data is expressed by grouping the monkeys as normoglycemic (fasting glucose $<140 \mathrm{mg} / \mathrm{dl}$, open bar), or hyperglycemic (fasting glucose $\geqslant 140 \mathrm{mg} / \mathrm{dl}$, solid bar). No difference was found between the two groups. $(B)$ Monkeys were separated into four groups based upon the known natural progression to NIDDM: Normal $=$ normoglycemic/normoinsulinemic $(\mathrm{M} 1-\mathrm{M} 6)$; Prediabetic $=$ normoglycemic/hyperinsulinemic (M7-M12); Early NIDDM = hyperglycemic/hyperinsulinemic (M13 and M14); Late NIDDM $=$ hyperglycemic/hypoinsulinemic (M15-M19). (C) Due to the small number of subjects in the early NIDDM group, the two hyperinsulinemic groups shown in $B$ were combined (hatched bar). (D) Monkeys were grouped by fasting plasma insulin (fasting insulin $>80 \mu \mathrm{U} / \mathrm{ml}$ was considered hyperinsulinemia).

receptor gene in this model. Our goal was first to determine the nucleotide sequence of the rhesus insulin receptor gene in the region of interest, and to characterize the pattern of alternate mRNA splicing in several tissues including two different regions of fat and muscle. Most importantly, we sought to determine if changes in alternate mRNA splicing occur in muscle from monkeys during the known progression from normal to overt diabetes.

Sequence analysis of exons 9 through 12 of the rhesus insulin receptor gene revealed that this region is very similar to humans and rats, and that alternate mRNA splicing also occurs in rhesus monkeys. These findings, combined with the observation that patterns of expression between tissues are remarkably similar between species, provide support for regulated splicing with potential physiological significance. It is interesting that, although the pattern of alternative splicing is the same between human and rhesus, the rhesus tends to have more of the exon $11-$ mRNA splicing variant in all tissues examined. Since even normal lean rhesus monkeys have higher basal circulating insulin levels compared to humans ( $30-80$ vs $5-10 \mu \mathrm{U} / \mathrm{ml}$ ), whose amino acid sequence is identical in the two species (35), these data are consistent with the hypothesis that the relative amount of the exon $11 \mathrm{mRNA}$ splicing variants in other tissues, in addition to muscle, are subject to regulation by insulin (see below).

Comparison of the two insulin receptor mRNA splicing variants in two different muscle regions revealed a small but statistically significant higher relative amount of the exon 11- mRNA variant in vastus lateralis compared to rectus abdominis (Fig. 5 ). These findings may be due to intrinsic differences in the relative amounts of the two mRNA splicing variants in the myocytes themselves, perhaps relating to the proportion of slow and fast twitch fibers (36). Alternatively, these differences may be due to differences in the amount of intramuscular fat tissue present in the respective muscle regions.

Our studies in rhesus monkeys show that the relative amounts of the two insulin receptor mRNA splicing variants parallel circulating insulin levels, and not glycemia (Fig. $6 B$ and $C$ ). Thus, monkeys that are hyperinsulinemic (prediabetic or early NIDDM) have higher amounts of the exon 11- mRNA splicing variant than monkeys that are not hyperinsulinemic (normal or late NIDDM) (Fig. $6 \mathrm{D}$ ).

These studies may provide an explanation for the discrepancies reported by different groups. For example, the observations of Mosthaf et al. (22) and Kellerer et al. (23), that diabetic subjects have less of the exon 11- mRNA variant, may be explained if they were comparing normoglycemic subjects with high insulin levels (this study's prediabetic group) to diabetics (this study's late NIDDM group) (Fig. $6 \mathrm{~B}$ ). Similarly, the observations of Benecke et al. (27) and Hansen et al. (28), that there were no differences in alternate splicing variants between nondiabetic and diabetic subjects, could be explained if they were comparing normoglycemic subjects (this study's normal and prediabetic groups combined) with diabetic subjects (this study's early and late NIDDM groups combined) (Fig. $6 A$ ).

Insulin resistance and hyperinsulinemia, even in the presence of normoglycemia, are risk factors for developing NIDDM in both humans (37-39) and monkeys (30). Our findings provide the first direct evidence linking hyperinsulinemia with alterations in splicing of exon 11 of the insulin receptor gene. Although we have only examined the relative amounts of the two mRNA splicing variants and have not examined isoform expression, others have shown that the relative amounts of the two receptor isoforms expressed at the cell surface parallel their respective mRNA levels $(23,27)$.

Since the biological properties of the two insulin receptor isoforms are poorly understood, it is unclear whether alterations in their expression early in the course of developing diabetes 
is a primary defect or a secondary change due to hyperinsulinemia. If the exon $11-$ isoform, which has twofold greater binding affinity and better internalization, also has greater ability to mediate insulin's metabolic effects, the early increase in the relative amount of the exon 11 - isoform might lead to an increase in sensitivity that may be compensatory for a postreceptor deficit in insulin action. Later in the progression to diabetes, $\beta$ cell dysfunction leads to hypoinsulinemia, and a relative decrease in the amount of the exon 11- isoform. This decrease may contribute to worsening of apparent insulin action later in the course of the disease.

Alternatively, if some of the metabolic actions of insulin are transmitted better by the exon $11+$ isoform as reported by Kellerer et al. (18), and Kosaki et al. (40), the early increase of exon 11 - isoform might be a primary cause of insulin resistance. Although the changes in the relative amounts of the two insulin receptor mRNA splicing variants are small, if one considers that if hybrid ( $\alpha^{\text {Type A }} \alpha^{\text {Type B }} \beta_{2}$ ) receptors form freely, a relatively small change in expression from 60 to $75 \%$ type $A$ would result in a 2.5-fold decrease in the type $B\left(\alpha_{2} \beta_{2}\right)$ isoform from 16 to $6.25 \%$ type $B(41-43) .^{2}$ Further investigation to determine how alternate splicing is regulated, and the specific physiological properties of the two resulting receptor isoforms and their hybrids in vivo will be crucial to our understanding of the molecular mechanisms of insulin resistance.

\section{Acknowledgments}

The authors thank T. Alexander for excellent technical assistance in animal handling and characterization. We also wish to thank Jesse Roth for expert advice and encouragement, and John Sorkin for excellent statistical analyses.

This project was supported in part by the National Institutes of Health grants DK-37717, AG-10612 and AG-42100 (B. C. Hansen), and 5T32AG-00120, as well as the Mallinckrodt Foundation (A. R. Shuldiner) and the Chesapeake Education and Research Trust (A. R. Shuldiner).

\section{References}

1. DeFronzo, R. A., R. C. Bonadonna, and E. Ferrannini. 1992. Pathogenesis of NIDDM: a balanced overview. Diabetes Care. 15:318-368.

2. Granner, D. K., and R. N. O'Brien. 1992. Molecular physiology and genetics of NIDDM: importance of metabolic staging. Diabetes Care. 15:369-395.

3. Moller, D. E., and J. S. Flier. 1991. Insulin resistance: mechanisms, syndromes, and implications. N. Engl. J. Med. 325:938-948.

4. Häring, H. U., and H. Mehnert. 1993. Pathogenesis of type 2 (non-insulindependent) diabetes mellitus: candidates for a signal transmitter defect causing insulin resistance of the skeletal muscle. Diabetologia. 36:176-182.

5. Kahn, C. R., and F. Folli. 1993. Molecular determinants of insulin action. Horm. Res. (Basel). 39(Suppl. 3):93-101.

6. Rosen, O. M. 1987. After insulin binds. Science (Wash. DC). 237:14521458.

7. Ullich, A., J. R. Bell, E. Y. Chen, R. Herrera, L. M. Petruzzelli, T. J. Dull, A. Gray, L. Coussens, Y.-C. Liao, M. Tsubokawa, et al. 1985. Human insulin receptor and its relationship to the tyrosine kinase family of oncogenes. Nature (Lond.). 313:756-761.

8. Ebina, Y., L. Ellis, K. Jarnagin, M. Edery, L. Graf, E. Clauser, J.-H. Ou,

2. Calculations were based upon a simple binomial $A^{2}+2 A B+B^{2}$ $=1$, where $A=$ either 0.60 or 0.75 . The rhesus insulin receptor shows 99.9\% amino acid identity with the human insulin receptor throughout the entire coding region, and thus the properties of rhesus hybrid receptors are likely to be very similar to human hybrid receptors (Huang, $Z$., N. L. Bodkin, H. K. Ortmeyer, B. C. Hansen, and A. R. Shuldiner, manuscript in preparation).
F. Masiarz, Y. W. Kan, I. D. Goldfine, et al. 1985. The human insulin receptor c-DNA: the structural basis for hormone-activated transmembrane signalling. Cell. 46:747-758.

9. Seino, S., M. Seino, and G. J. Bell. 1990. Human insulin-receptor gene. Partial sequence and amplification of exons by polymerase chain reaction. Diabetes. 39:123-128.

10. Taylor, S. I., A. Cama, D. Accili, F. Barbetti, M. J. Quon, M. de La Luz Sierra, Y. Suzuki, E. Koller, R. Levy-Toledano, E. Wertheimer, et al. 1992. Mutations in the insulin receptor gene. Endocr. Rev. 13:566-595.

11. Moller, D. E., A. Yokota, and J. S. Flier. 1989. Normal insulin-receptor cDNA sequence in Pima indians with NIDDM. Diabetes. 38:1496-1500.

12. Moller, D. E., A. Yokota, J. F. Caro, and J. S. Flier. 1989. Tissue-specific expression of two alternatively spliced insulin receptor mRNA's in man. Mol. Endocrinol. 3:1263-1269.

13. Seino, S., and G. I. Bell. 1989. Alternative splicing of human insulin receptor messenger RNA. Biochem. Biophys. Res. Commun. 159:312-316.

14. Mosthaf, L., K. Grako, T. J. Dull, L. Coussens, A. Ulrich, and D. A. McClain. 1990. Functionally distinct insulin receptors generated by tissue-specific alternative splicing. EMBO (Eur. Mol. Biol. Organ.) J. 9:2409-2413.

15. Yamaguchi, Y., J. S. Flier, A. Yokota, H. Benecke, J. M. Backer, and D. E. Moller. 1991. Functional properties of two naturally occurring isoforms of the human insulin receptor in Chinese hamster ovary cells. Endocrinology. 129:2058-2066.

16. McClain, D. A. 1991. Different ligand affinities of the two human insulin receptor splice variants are reflected in parallel changes in sensitivity for insulin action. Mol. Endocrinol. 5:734-739.

17. Carrascosa, J. M., B. Vogt, A. Ullrich and H. U. Häring. 1991. Activation of phosphatidylinositol-3-kinase by insulin is mediated by both A and B human insulin receptor types. Biochem. Biophys. Res. Commun. 174:123-127.

18. Kellerer, M., R. Lammers, B. Ermel, A. Ullrich, and H. U. Häring. 1992. Distinct $\alpha$-subunit structures of human insulin receptor A and B variants determine differences in tyrosine kinase activities. Biochemistry. 31:4588-4596.

19. Vogt, B., J. M. Carrascosa, B. Ermel, A. Ullrich, and H. U. Häring. 1991. The two isotypes of the human insulin receptor (HIR-A and HIR-B) follow different internalization kinetics. Biochem. Biophys. Res. Commun. 177:10131018.

20. Muhlhofer, A., M. Kellerer, L. Berti, R. Schumacher, K. Seedorf, L. Mosthaf, and H. U. Häring. 1993. Characterization of IRS-1 interaction with both insulin receptor isoforms. Exp. Clin. Endocrinol. 101 (Suppl. 2):125-127. (Abstr.)

21. Yamaguchi, Y., J. S. Flier, H. Benecke, B. J. Ransil, and D. E. Moller. 1993. Ligand-binding properties of the two isoforms of the human insulin receptor. Endocrinology. 132:1132-1138.

22. Mosthaf, L., B. Vogt, H. Häring, and A. Ullrich. 1991. Altered expression of insulin receptor types A and B in the skeletal muscle of non-insulin-dependent diabetes mellitus patients. Proc. Natl. Acad. Sci. USA. 88:4728-4730.

23. Kellerer, M., G. Sesti, E. Seffer, B. Obermaier-Kusser, D. E. Pongratz, L. Mosthaf, and H. U. Häring. 1993. Altered pattern of insulin receptor isotypes in skeletal muscle membranes of type II (non-insulin-dependent) diabetic subjects. Diabetologia. 36:628-632.

24. Mosthaf, L., J. Eriksson, H. U. Häring, L. Groop, E. Widen, and A Ullrich. 1993. Insulin receptor isotype expression correlates with risk of noninsulin-dependent diabetes. Proc. Natl. Acad. Sci. USA. 90:2633-2635.

25. Sesti, G., M. A. Marini, A. N. Tullio, A. Montemurro, P. Borboni, A. Fusco, D. Accili, and R. Lauro. 1991. Altered expression of the two naturally occurring human insulin receptor variants in isolated adipocytes of non-insulindependent diabetes mellitus subjects. Biochem. Biophys. Res. Commun. 181:1419-1424.

26. Norgren, S., J. Zierath, D. Galuska, H. Wallberg-Henriksson, and H. Luthman. 1993. Differences in the ratio of RNA encoding two isoforms of the insulin receptor between control and NIDDM patients: the RNA variant without exon 11 predominates in both groups. Diabetes. 42:675-681.

27. Benecke, H., J. S. Flier, and D. E. Moller. 1992. Alternatively spliced variants of the insulin receptor protein. Expression in normal and diabetic human tissues. J. Clin. Invest. 89:2066-2070.

28. Hansen, T., C. Bjorbaek, H. Vestergaard, K. Gronskov, J. F. Bak, and O. Pedersen. 1993. Expression of insulin receptor spliced variants and their functional correlates in muscle from patients with non-insulin dependent diabetes mellitus. J. Clin. Endocrinol. \& Metab. 77:1500-1505.

29. Bodkin, N. L., B. L. Metzger, and B. C. Hansen. 1989. Hepatic glucose production and insulin sensitivity preceding diabetes in monkeys. Am. J. Physiol. 256:E676-E681

30. Hansen, B. C., and N. L. Bodlin. 1990. Beta-cell hyperresponsiveness: earliest event in development of diabetes in monkeys. Am. J. Physiol. 259:R612R617.

31. Hansen, B. C. 1992. Obesity and diabetes in monkeys. In Obesity. P. Bjorntorp and B. Brodoff, editors. J. B. Lippincott Co., Philadelphia. 256-265.

32. Shuldiner, A. R., and Z. Huang. 1994. Reducing false positives with RNA template-specific PCR (RS-PCR). In Reverse Transcriptase-PCR. J. W. Larrick and P. D. Siebert, editors. Simon and Schuster, New York. In press. 
33. Goldstein, B. J., and A. L. Dudley. 1990. The rat insulin receptor: primary structure and conservation of tissue-specific alternative messenger RNA splicing. Mol. Endocrinol. 4:235-244.

34. Flores-Riveros, J., E. Sibley, T. Kastelic, and M. D. Lane. 1989. Substrate phosphorylation catalyzed by the insulin receptor tyrosine kinase. Kinetic correlation to autophosphorylation of specific sites in the $\beta$-subunit. J. Biol. Chem. 264:21557-21571.

35. Naithani, V. K., G. J. Steffens, H. S. Tager, G. Buse, A. H. Rubenstein, and D. F. Steiner. 1984. Isolation and amino acid sequence determination of monkey insulin and proinsulin. Hoppe-Seyler's Z Physiol. Chem. 365:571-575.

36. Johnson, M. A., P. D. Weightman, and D. Appleton. 1973. Data on the distribution of fibre types in thirty-six human muscles: an autopsy study. J. Neuro. Sci. 18:111-129.

37. Kadowaki, T., Y. Miyake, R. Hagura, Y. Akunama, H. Kajinuma, N. Kuraya, F. Takaku, and K. Tasaku. 1984. Risk factors for worsening to diabetes in subjects with impaired glucose tolerance. Diabetologia. 26:44-49.

38. Saad, M. F., W. C. Knowler, D. J. Pettitt, R. G. Nelson, P. H. Bennett.
1988. The natural history of impaired glucose tolerance in the Pima Indians. $N$. Engl. J. Med. 319:1500-1509.

39. Haffner, S. M., M. P. Stern, B. D. Mitchell, H. P. Hazuda. 1990. Incidence of type II diabetes in Mexican Americans predicted by fasting insulin and glucose levels obesity and body-fat distribution. Diabetes. 39:283-288.

40. Kosaki, A., and N. J. G. Webster. 1993. Effect of dexamethasone on the alternative splicing of the insulin receptor mRNA and insulin action in HepG2 hepatoma cells. J. Biol. Chem. 268:21990-21996.

41. Frattali, A., J. L. Treadway, and J. E. Pessin. 1992. Transmembrane signaling by the human insulin receptor kinase. J. Biol. Chem. 267:19521-19528.

42. Treadway, J. L., B. D. Morrison, M. A. Soos, K. Siddle, J. Olefsky, A. Ullrich, D. A. McClain, and J. E. Pessin. 1991. Transdominant inhibition of tyrosine kinase activity in mutant insulin/insulin-like growth factor I hybrid receptors. Proc. Natl. Acad. Sci. USA. 88:214-218.

43. Chin, J. E., J. M. Tavare, L. Ellis, and R. A. Roth. 1991. Evidence for hybrid rodent and human insulin receptors in transfected cells. J. Biol. Chem. 266:15587-15590. 